Justyna Kiliańczyk-Zięba (i) https://orcid.org/0000-0001-6592-4747

Jagiellonian University in Kraków

justyna.kilianczyk-zieba[at]uj.edu.pl

\title{
On the Diploma of Nobility of Jan Januszowski and a Portrait of a Renaissance Printer ${ }^{*}$
}

\begin{abstract}
Jan Januszowski, best known as Jan Kochanowski' friend, was the most distinguished printer of the Polish Renaissance. Januszowski, a lawyer educated in Cracow and Padua, was an extremely versatile man: an outstanding printer, as well as a prolific writer and translator. For all his achievements, he was ennobled by Sigismund III Vasa, and-happily - the diploma of nobility of Jan Januszowski, penned on parchment and splendidly illuminated, survived to the present day. The illumination of the document is rich and sumptuous. It shows the coats-of-arms representing the provinces of the Polish Kingdom and Grand Duchy of Lithuania and small portraits: three of them depict Polish kings, the fourth is of Januszowski himself-it is one of the very few known portraits of Polish Renaissance intellectuals and the oldest portrait of a Polish printer. The document's decoration is not only beautiful, but also meaningful, as its content and composition reflects the nature of the state-the
\end{abstract}

* Publication of this paper was financed by the Ministry of Science and Higher Education of the Republic of Poland under the grant 643/P-DUN/2018. Polish version: J. Kiliańczyk-Zięba, "O dyplomie nobilitacyjnym Jana Januszowskiego i portrecie renesansowego wydawcy", Terminus 10 (2008), issue 1, pp. 61-87. The author would like to thank Professor Janusz Gruchała, Professor Wojciech Krawczuk, and Mrs Danuta Jackiewicz, the curator of the Iconographic and Photographic Collections of the National Museum in Warsaw for their kind reading and valuable comments. 
Polish-Lithuanian Commonwealth-and suggests Januszowski's important place in its structure and strong links between the printer and the most important dignitaries of the country.

Keywords: Jan Januszowski, Polish Renaissance literature, diploma of nobility, heraldry, charters, Renaissance printing houses, book history

Jan Lazarides Januszowski was certainly an extraordinary figure. In the history of Polish culture, he appeared as an "exceptional typographer" - the head of Officina Lazari (Oficyna Łazarzowa), one of the most outstanding printers of Polish Renaissance, publisher of Jan Kochanowski's works, among others.

Januszowski was not only a printer who knew his trade, but also a man with the horizons and interests of a Renaissance humanist. Comprehensively educated, he enrolled first at the University of Cracow (where Jakub Górski was his master) and later in Padua, where he studied law and rhetoric under Riccoboni. He received practical education at the courts of Emperor Maximilian II, Sigismund Augustus, and Stephen Báthory, and spent a significant part of his youth in the royal chancery of Polish monarchs, in a truly elite environment. He spoke several languages and his activity was not limited to printing books. He was also a prolific writer and an excellent translator, and the extensive legacy he left behind proves that he was no less interested in legislation, social journalism, historiography, astrology, and theology than in the operation of his printing house. ${ }^{2}$

${ }^{1}$ Januszowski was named so by Tomasz Płaza in a letter to Bishop Marcin Kromer, cited as in: S. Bodniak, "W oficynie „architypografa”. Rzecz o kłopotach Januszowskiego", Silva Rerum 5 (1930), p. 140.

${ }^{2}$ See A. Kawecka-Gryczowa, "Jan Januszowski", in Drukarze dawnej Polski, vol. 1: Małopolska, part 1: Od XV do XVI wieku, ed. A. Kawecka-Gryczowa, Wrocław 1983, pp. 69-99; J. Kiliańczyk-Zięba, Czcionką i piórem. Jan Januszowski w roli pisarza i tłumacza, Cracow 2007. 
The various intellectual passions and great diligence of Januszowski were appreciated by his contemporaries, both scholars and poets, who were willing to entrust his publishing house with their works, as well as magnates patronising some of his publishing and writing activities. The recognition of Januszowski's achievements and his "talents and virtues" was also reflected in the diploma of nobility he received from Sigismund III Vasa in 1588, at a time when it was becoming increasingly difficult to become a nobleman. ${ }^{3}$

Awarding nobility for outstanding intellectual achievements (which were often combined with merits of a different, usually political character) had a long tradition. Nobility was awarded to talented chancery clerks, professors of the University of Cracow and men of letters, including preacher Stanisław Sokołowski (1571), historian Reinhold Heidenstein (1585), historian Marcin Kromer (1552), and Szymon Szymonowic (1590). ${ }^{4}$ The motivation for Januszowski's ennoblement was, however, exceptional. It was not so much the merit of a royal secretary or writer as the importance of a man who, with all his versatility, was above all a printer-a master of the "black art". Of course, a few years earlier, in 1581, Stephen Báthory ennobled Walenty Łapka (Łapczyński). However, the executive of the "Flying Printing House"

3 "By 1578 , the king could have ennobled people with virtually no limits. The increasing number of ennoblements ... caused a reaction of the nobility. The Constitution of 1578 states that a king may ennoble only at a Sejm with the consent of deputies and senators. However, there was still loop-hole that allowed the king to confer quite numerous ennoblements for military merits, which could be awarded even on the battlefield .... In such cases, the nearest Sejm congregation approved the ennoblement .... The way Stephen Bathory and later Sigismund III Vasa evaded the law in granting nobility resulted in a much stronger reaction of the Sejm. In 1601, the Sejm decided that the only way to ennoble someone is through the Sejm constitution". As cited in: B. Trelińska, Album armorum nobilium Regni Poloniae XV-XVIII saec. Herby nobilitacji i indygenatów XV-XVIII w., Lublin 2001, p. 7.

${ }^{4}$ Trelińska, Album, p. 16; S. K. Kuczyński, "Nobilitacja Szymona Szymonowica”, Rocznik Lubelski 25/26 (1983/1984), pp. 31-43. 
was, first and foremost, awarded for his bravery in war, although his diploma of nobility also mentions "merits displayed at the printing press". Nobility awarded to Januszowski's for his intellectual work was certified by a diploma issued by the chancery of Sigismund III Vasa. ${ }^{6}$ It

5 A. Kawecka-Gryczowa, "Dzieje 'Drukarni Latającej”, Rocznik Biblioteki Narodowej 7 (1971), p. 356. Bartosz Paprocki commented on this ennoblement, also giving his opinion on the value of printing art: "Walenty Łapczyński was a printer, who turned printing into an ornament of his noble estate because it is art as all other arts, which does not offend not only the populace, but also vere ipsum nobilem. Indeed, he deserved this reward during the expedition to Muscovy, when he displayed courage comparable to that of knights". As cited in: B. Paprocki, Herby rycerstwa polskiego, ed. K. J. Turowski, Cracow 1858, p. 280. The Szarfenberg family also became noble; in 1554 they were ennobled by Ferdinand I, the Roman, Hungarian and Czech king (later emperor). This is why the Cracow heirs of Marek Szarfenberg used a printer's device in the form of a coat of arms. See A. Birkenmajer, Nobilitacja Szarffenbergerów, Cracow 1926, p. 10. Similarly, Cyprian Bazylik adopted under the heraldic coat of arms and surname of Heraklides Jakub Basilikos, which was confirmed in 1557 by Sigismund Augustus. See A. Kawecka-Gryczowa, "Bazylik Cyprian", in Drukarze dawnej Polski od XV do XVIII wieku, vol. 5: Wielkie Księstwo Litewskie, ed. A. Kawecka-Gryczowa, K. Korotajowa, and W. Krajewski, Wrocław 1959, p. 45.

${ }^{6}$ Januszowski's diploma of nobility is kept in the National Museum in Warsaw (Iconographic and Photographic Collections, shelf mark 1793). The document was donated to the museum by Dominik Witke-Jeżewski, a collector who donated his collections (including graphics, drawings, woodcuts) to the institution in the years 1917-1939. See P. P. Czyż, "Dominik Witke-Jeżewski”, in Miłośnicy grafiki i ich kolekcje w zbiorach Muzeum Narodowego w Warszawie, ed. E. Zdonkiewicz, Warsaw 2006, pp. 116-119. The text of the diploma (abridged) was also entered into the Crown Metrica (today in the Central Archives of Historical Records, number 134, ff. $65 \mathrm{v}-68 \mathrm{v}$ ). The text of the document was reprinted (in the abridged version obtained from the Metrica) by T. Wierzbowski in Materiaty do dziejów piśmiennictwa polskiego, Warsaw 1900, p. 278, and J. Ptaśnik in Cracovia impressorum XV et XVI saeculorum, Lviv 1922 (Monumenta Poloniae Typographica I), pp. 363-364. The full text of the privilege as it appears in the original was published by J. Michta in Nobilitacja Jana Januszowskiego wystawiona w Krakowie, 24 stycznia 1588 roku, Kielce 1991 (Nobilitacje i Indygenaty w Rzeczypospolitej 1434-1794, no. 3), where the diploma was also reproduced. A reproduction of the document, with a note by Danuta Jackiewicz, is also included in Muzeum Narodowe w Warszawie. Przewodnik po galeriach stałych i zbiorach 
owes its unique character not only to the fact that it is one of the most beautifully illuminated documents that came out of the Polish royal chancery and survived until our times. Januszowski's diploma is also valuable because its rich decoration preserved for us his image-the first known portrait of a Polish printer ${ }^{7}$ and at the same time one of the rare veristic portraits of an intellectual of the Polish Renaissance.

The diploma of nobility was principally a document commemorating a legal act, one of extraordinary significance: the acquisition by a 'new man' and his family of all the rights of a nobleman. ${ }^{8}$ Therefore, those who entered the noble state financed the preparation of a diploma, which was a solemn form of authenticating the nobility. Thus, the grandeur of the document was primarily determined by the wealth of the ennobled, but his aesthetic preferences were not without significance. Januszowski's diploma of nobility-drawn up on a huge parchment card (measuring 57.5 by 81 centimetres), with a royal seal hung on a silk three-colour cord, with carefully calligraphed text and decoration made not only with egg tempera, but also with powdered gold-proves that both Januszowski's requirements and expenses associated with issuing the document must have been significant. These

studyjnych, ed. K. Murawska-Muthesius, D. Folga-Januszewska, Warsaw 1998, p. 441.

7 A portrait of Januszowski would be the first preserved veristic image of a Polish printer, if one could consider Kazimierz Piekarski's assumptions to be insufficiently substantiated: “One would whish to complement Ungler's characteristics with his image. Well, when we look at the expressive face of St Florian in the woodcut of printer's device ..., it seems to me that our typographer was the model for the artist in reconstructing the features of the saint". As cited in: K. Piekarski, Pierwsza drukarnia Floriana Unglera, 1510-1516, Cracow 1926, p. 21. There is a beautiful portrait of a printer who worked later than Jan Januszowski, namely Franciszek Cezary. See S. Tomkowicz, Przyczynki do historii kultury Krakowa w pierwszej połowie XVII wieku, Lviv 1912.

8 Apart from this basic function, documents-including Januszowski's diploma-played other important culture-formative roles. See W. Chorążyczewski, "Nowożytny dokument królewski. Możliwości badawcze", in Polska kancelaria królewska czasów nowożytnych. Między władzą a społeczeństwem, ed. W. Chorążyczewski and W. Krawczuk, Toruń 2003, p. 28 et. seq. 
included not only the costs of expensive writing or painting materials, but also highly skilled calligraphers and illuminators as the beautiful decoration of the diploma is a manifestation of artistry and has a complex iconographic programme.

For practical reasons, the ennobled wanted the perpetual character of this official decision to be reflected not only in documents kept for future generations in the family's papers, but also in the files of the Crown archive. Therefore, they also paid high chancery fees for issuing or sealing the document, as well as for entering it into the Crown Metrica. ${ }^{9}$ Januszowski, who had a legal education and secretarial practice, ${ }^{10}$ made sure that the text of the privilege of his ennoblement was included in the files kept by the chancery.

The books of the Crown Metrica had the character of registers, to which royal secretaries entered the content of documents issued by the chancery, abridging the standard parts. The whole text appeared on diplomas. ${ }^{11}$ Until the mid-eighteenth century, such diplomas were written in Latin. Traditionally, formulas and design of old, still mediaeval provenance were used. ${ }^{12}$ The text of Jan Januszowski's diploma of nobility was also arranged in accordance with models developed over centuries. It begins with a call to the divine name (invocation) and an emphasis on the perpetual character of the legal act (perpetuation), followed by the intitulation, that is, the giving of the name and dignity of the royal grantor of the document. Then, among the

9 A. Tomczak, "Kilka uwag o kancelarii królewskiej w drugiej połowie XVI wieku”, Archeion 37 (1962), p. 248.

${ }^{10}$ Cf. M. Korolko, Seminarium Rzeczypospolitej Królestwa Polskiego. Humaniści w kancelarii królewskiej Zygmunta Augusta, Warsaw 1991, pp. 206-207.

${ }^{11}$ I. Sułkowska-Kurasiowa, "Księgi wpisów Metryki Koronnej (1447-1794) w Archiwum Głównym Akt Dawnych w Warszawie", Archeion 44 (1966), pp. 73-74. This was also the case with the privilege for Januszowski, in which the standard parts, such as the superscription (intitulatio) and the list of witnesses, were abridged.

${ }_{12}$ Michta, Nobilitacja, pp. 11-12. The terminology used follows: J. Szymański, Nauki pomocnicze historii, Warsaw 2006, pp. 448-450 and I. Sułkowska-Kurasiowa, Dokumenty królewskie i ich funkcja w państwie polskim za Andegawenów i pierwszych Jagiellonów, 1370-1444, Warsaw 1977, pp. 13-48. 
other parts of the form, we find the preamble (arenga), which generally explains the reasons for issuing the document with the desire to reward a virtue that serves the country (although it does not necessarily manifest itself during the war) and the narrative, that is, the life and merits of the ennobled. Although this part of the text of the diploma is also strongly conventionalised, it is a source of biographical information about Januszowski, such as the origin of his ancestors, his studies, and the years spent at royal courts. We can also find here a list of Januszowski's virtues, whose works bring benefits not only to the Polish-Lithuanian Commonwealth, but also to the Catholic Church. There are mentions of Stephen Báthory's kindness to the printer and a discreet hint of the patronage of "senators of great authority" who influenced Sigismund's gracious decision. In the next part of the document, there is an extensive dispositio (ordo), that is, a declaration of will by Sigismund III Vasa, who makes Jan Lazarides Januszowski a nobleman, followed by a description of the Kłośnik coat of arms granted to the printer. The document ends with a customary formula of corroboration (which mentions the affixing of the royal signature and seal to the document) and date, as well as a long list of witnesses to the event. The lower part of the parchment card is bent and interwoven with a cord, thus protecting the handwritten signature of Sigismund III Vasa.

The diploma of nobility was written on parchment with a clear and legible minuscule Antiqua, which in the sixteenth century was used only in the most splendorous documents. ${ }^{13}$ A skilled calligrapher had no difficulty with designing the layout of the text: he maintained an even spacing between letters and expressions, as well as a fixed length and width of lines. He distinguished the enumeration of part of the royal titles in the heading, switching to a larger calligraphic variant of the hand used in the main text of the diploma, and highlighted the recurring names of Januszowski with a majuscule and gold plating.

${ }_{13}$ See J. Słowiński, Rozwój pisma łacińskiego w Polsce w XVI-XVIII wieku. Studium paleograficzne, Lublin 1992, p. 26. 
While the wide vertical margins and the bottom margin are decorated with ornaments, the upper margin is filled with a call to the divine name and an outstanding majestic "Sigismundus Tertius" written in Roman square capitals. The composition of the document required that the first letter of invocation and the last letter of the royal grantor's name would be large and decorative, but although the scribe left empty space in appropriate places, the illuminator, who apparently did not finish decorating the document, never painted those "I" and "S". On the other hand, the initials of the name of Sigismund III Vasa were beautifully distinguished: placed on the margin and merged with the image of an eagle-the national coat of arms of the Kingdom of Poland.

Pushing the royal initial to the margin and filling the first line of the text with the monarch's name was a compositional device often used in documents that came out of the royal chancery. While preparing diplomas of nobility, the image of the coat of arms of the new nobleman was placed centrally, as it was also traditionally done in the imperial chancery. ${ }^{14}$ This tried and tested design was also used in Januszowski's diploma, where the Kłośnik coat of arms given to the printer, the most prominent visual symbol of the change in the social status of a burgher, was presented in the middle of the parchment card in a large architectural frame. The Kłośnik is "an argent lily in a gules field on a vert twig, affixed on an or base". ${ }^{15}$ It is the first known coat of arms derived from the Vasa family heraldic badge, the vase (Swedish for sheaf). Januszowski’s diploma features the Kłośnik in the form of heraldic achievement, in which a helmet with a closed visor, as well as gules mantling with argent lining in the shape of imaginatively twisted acanthus leaves were added to the shield. On top of the escutcheon, there is a helmet with an or crown decorated with rubies and emeralds. The abundant mantling falls down from the crown. The latter supports the crest, which is a repetition of the badge

${ }^{14}$ Michta, Nobilitacja, no. 2, p. 7.

15 The colours are, respectively, silver, red, green, and gold-K. S. 
from the field of the escutcheon. The whole composition is placed on a simple compartment, and the background for the whole heraldic composition is an azure field enclosed with an arcade. By the way, it is worth mentioning that the Kłośnik painted on Lazarides' diploma of nobility is one of the few sixteenth-century Polish iconographic artefacts which present new coats of arms as visual representations of heraldic achievements were expensive. ${ }^{16}$ Januszowic was apparently ready to bear the cost.

The first biographer of Januszowski, Szymon Starowolski, who saw Januszowski's diploma of nobility, highly valued the proficiency with which the coat of arms given to the noble printer was painted on the document. ${ }^{17}$ The opinion of the polymath is confirmed by contemporary scholars, who describe the heraldic images preserved in the diplomas of nobility issued by the chancery of Sigismund III Vasa in the first years of his reign as masterfully executed. ${ }^{18}$

The anonymous artist who worked on the illumination of the diploma analysed here not only meticulously presented Januszowski's coat of arms, but also, as already mentioned, surrounded the calligraphed text of the document with a decorative bordure. The side and bottom margins of the parchment card were tightly filled with a carefully drawn colourful decoration: a floral twig, harmoniously connected with the coats of arms of the Polish-Lithuanian Commonwealth, pennants, insignia of royal power, and finally-portraits.

16 Szymański, Nauki, p. XIII.

17 "This Kłośnik coat of arms is depicted on the document of conferment, painted with a hand skilled in this art”. As cited in: S. Starowolski, Setnik pisarzów polskich, ed. F. Bielak and J. Starnawski, transl. J. Starnawski, Cracow 1970, p. 217. Starowolski not only looked at the diploma, but also read the document confirming Januszowski's ennoblement. It seems that the passus about Januszowski's youth, which Starowolski placed in the printer's biography in his Setnik, was inspired by the text of the diploma.

${ }^{18}$ Michta, Nobilitacja, no. 2, p. 10; A. Jaworska, "Znaki władcy i państwa w heraldyce nobilitacji i indygenatu w Polsce", in Ludzie i herby w dawnej Polsce, ed. P. Dymmel, Lublin 1995, p. 144. 
The illumination of a wide margin opens with the presentation of the coat of arms of the Kingdom of Poland. The crowned argent eagle, painted with meticulous precision, has an elongated ovalshaped silhouette, a heart-shaped torso that continues into an ornamentally elaborated tail with several bands and widely spread wings with concentrically pinned flight feathers. A small head with an open predatory bow faces right; bent legs are armed with claws. A closer look at the elegant silhouette of the bird reveals that the painting decoration of Januszowski's diploma was made by a miniature artist who knew his trade and tastes of the epoch well, who used tried and tested graphic models in accordance with the tradition of the Cracow circle of illuminators: the manneristic image of the eagle from the end of the sixteenth century was widely spread in book illustrations and official heraldic designs on seals or coins, and in the first half of the seventeenth century it became a classic visual formula. ${ }^{19}$

Distinguished by good proportions and subtle painterly modelling of the eagle, it is the largest of the elements that make up the artistic decoration of the document. However, the viewer's attention is drawn not only by the size of the heraldic bird and the mastery of illumination, but also by its location. It is placed in the exposed upper left corner of the parchment card, on a bright, light-filled background and in such a way that the royal cypher, the letter $S$ formed from two stylised twigs, could be further used as the initial of the name of Sigismund III Vasa. Such a composition has not only a visual value, but also an ideological meaning: the state arms are certainly deliberately depicted on the right-hand side of the diploma (heraldically speaking), commonly considered the most honourable, and its interweaving with the royal monogram (a motif introduced into heraldry by Sigismund the Old and willingly used by his successors)

19 A. Jaworska, Orzeł biały. Herb państwa polskiego, Warsaw 2003, p. 176. 
was a very clear expression of the organic relationship between the ruler and the state. ${ }^{20}$

The elongated tail of the royal Eagle was skilfully used as a motif that combined the arms of the Kingdom with other elements of the bordure decoration. There were two pennants on its sides, with the coat of arms of Podolia and the cross of Volhynia, ${ }^{21}$ the first of the rich set of territorial arms present in the illuminated decoration. The shafts are stuck into an arched crown inlaid with jewels, painted slightly lower. On the intersection of the arches, there was an orb called mundus with a cross. It symbolises the equality between the imperial power and the sovereignty of the Polish king's reign. ${ }^{22}$ Inside the crown, other regalia intersect as well: a slim sceptre symbolising just government and a naked sword symbolising the strength of the monarch and his duty to defend his subjects. ${ }^{23}$ The royal insignia are held by a pair of kneeling angels. The use of angelic figures, rather than the putti of ancient origin, often used in sixteenth-century iconography, should probably be treated as a consequence of the mediaeval legal doctrine of the divine origin of the power entrusted to the king. The phrase Dei gratia, which appears in the titles of the Polish rulers and is calligraphed in Januszowski's diploma of nobility, is of the same origin. ${ }^{24}$

${ }^{20}$ Z. Piech, "Zarys dziejów i symbolika orła białego", in Orły nasze. Orzeł biały w zbiorach Biblioteki Jagiellońskiej, ed. M. Rokosz, Cracow 1996, p. 26.

${ }^{21}$ Identifying the coats of arms present in the diploma, I used the information presented in S. K. Kuczyński, Polskie herby ziemskie. Geneza, treści, funkcje, Warsaw 1993.

${ }^{22}$ See A. Gieysztor, "Non habemus caesarem nisi regem. Korona zamknięta królów polskich w końcu XV wieku i w wieku XVI", in Muzeum i twórca. Studia $z$ historii sztuki i kultury ku czci prof. Stanisława Lorentza, ed. K. Michałowski et al., Warsaw 1969, pp. 277-292; B. Miodońska, "Korona zamknięta w przekazach ikonograficznych z czasów Zygmunta I”, Biuletyn Historii Sztuki 32 (1970), no. 1, pp. 3-15.

${ }^{23}$ See J. Lileyko, Regalia polskie, Warsaw 1987, p. 5; J. A. Chrościcki, Sztuka i polityka. Funkcje propagandowe sztuki w epoce Wazów, 1587-1668, Warsaw 1983, pp. 30-31.

${ }^{24}$ Piech, "Zarys dziejów”, p. 27. 
The angels holding the crown seem to be closing the initial part of the bordure decoration. The crown serves as an introduction, symbolises the state and its king, who depends only on God and bestows nobility on one of his subjects. The portrait Sigismund III Vasa is below the arms of the Kingdom, interwoven with the royal monogram and the insignia representing the monarch's power.

An oval cartouche with an image of Sigismund in it blooms from a plant stem that winds along the bottom margin and climbs up the side margins. Apart from a few more portrait frames, the green stem also sprouts stylised buds, leafy twigs and colourful representations of the territorial coats of arms of the Polish-Lithuanian Commonwealth. More than thirty heraldic drawings framed in delicate floral petals represent the provinces, voivodeships, and lands of the PolishLithuanian state. It includes the arms of territories long under the rule of the Polish Crown (for example, the land of Cracow, Dobrzyn, Sandomierz, or Ruthenia), as well as those incorporated into the Kingdom at the end of the fifteenth and sixteenth centuries (including the Duchies of Zator, the Rawa, Polatsk and Kiev voivodeships), the Moldavian fiefdom, and the Smolensk province, which has the character of a claim. In addition to the arms of the Crown territories, the decoration of the diploma also presents the arms of Lithuanian lands, including the Navahrudak and Samogitian provinces, as well as Livonia, which are the condominiums of the Grand Duchy of Lithuania and the Kingdom of Poland. A crowned cartouche with the coat of arms of Sweden and Gotland is near the portrait of Sigismund III Vasa as he was also King of Sweden.

The iconographic programme of the diploma also included $\mathrm{Pa}-$ honia: the coat of arms of Lithuania, crowned with a princely mitre, was separated from the bordure and painted above the text of the document, at the same level as the Eagle. Although the Lithuanian coat of arms was much smaller, its spatial alignment with the Kingdom's arms was probably a way of emphasising the role that the territories represented by the Eagle and the Pahonia played in the Polish-Lithuanian Commonwealth. It also seems that Pahonia was to be interwoven with cypher $\mathrm{S}$ too and thus connected with the name 
of Sigismund III Vasa. The composition of the diploma suggests that the coat of arms of Lithuania was to be encircled by the last letter of "tertius", which should end the royal name, a letter potentially as big and ornamental as the initial S, which, however, the illuminator of the document never painted. The visual "ties" with the royal name had a symbolic value. The iconographic programme of Januszowski's diploma apparently included the merging of the name symbolising the ruler with the arms of the Crown and Lithuania, which represented the Commonwealth. In this way, not only the relationship between the state and the king was depicted, but also the "Jagiellonian myth" was promoted, showing Sigismund III as a Jagiellonian on the distaff side and the Vasas as the royal family ruling in Poland since the end of the fourteenth century and in Lithuania since the thirteenth century. ${ }^{25}$

The territorial emblems presented on the diploma of nobility issued by Sigismund III Vasa's chancery to Januszowski were numerous and diverse. Of course, they did not represent all the lands since even the royal great seals, considered to be a model of this type of heraldic composition, did not display a complete set of arms. ${ }^{26}$ The bordure of the parchment document, which began with the image of the crowned Eagle and closed with the Lithuanian Pahonia, was not to document the territories within the Polish-Lithuanian Commonwealth. Instead, with the language of heraldic symbols, it expressed the idea of a united state that consisted of many lands with their own individual traditions, which grew into one body. It was also a visual representation of and complement to the royal titles, which began the text of the diploma. ${ }^{27}$

The iconographic tradition showed the king's person as a factor that integrated the lands of the vast state and at the same time guaranteed the sovereignty of the Commonwealth. Therefore, in

25 Chrościcki, Sztuka i polityka, pp. 35-36.

26 Kuczyński, Polskie herby ziemskie, pp. 123-134.

27 Piech, “Zarys dziejów”, pp. 20-21. 
sixteenth-century Polish art, royal portraits in combination with a large set of territorial arms were not uncommon. Such compositions, well known especially from seals, paintings and graphic representations (especially in official prints and works of historians), were not only a clear manifestation of the concept of an organic relationship between the ruler and his dominion. They were understood and interpreted as symbolic representations of the state itself, in which the king acted as a keystone. ${ }^{28}$ These concepts were also referred to by the creator of the decoration of Januszowski's diploma, who planned to include portraits of four consecutive rulers of the Polish throne in the illumination of the document. The artist managed to realise this intention only in part as in the medallions surrounded by a cartouche ornament he painted images of Sigismund III Vasa, Stephen Báthory, and Henry III of France, but he left the oval frame prepared for the portrait of Sigismund II Augustus empty.

The gallery of royal likenesses on Januszowski's diploma of nobility opens with an image of the ruler who bestowed the noble status on him. The portrait of Sigismund III Vasa was painted "in Marcin Kober's fashion", referring to the images of the King associated with the "portrait of the king painted by Kober in Warsaw on 30 April 1591, which was dated and signed by the painter". ${ }^{29}$ The miniature on Januszowski's diploma resembles this portrait in terms of composition

${ }_{28}$ See B. Miodońska, "Przedstawienie państwa polskiego w Statucie Łaskiego z r. 1506”, Folia Historiae Atrium 5 (1968), pp. 38-47.

${ }^{29}$ See J. Ruszczycówna, "Portrety Zygmunta III i jego rodziny”, Rocznik Muzeum Narodowego $w$ Warszawie 13 (1969), no. 1, p. 160. There are several known images of Sigismund III Vasa modelled on this portrait (reproduced in the quoted paper and in the works T. Petrus, "Miniaturowa galeria portretów rodziny Zygmunta III", Biuletyn Historii Sztuki 37 (1975), pp. 150-161 and Sztuka dworu Wazów w Polsce. Wystawa w Zamku Królewskim na Wawelu, maj-czerwiec 1976. Katalog, ed. A. Fischinger, Cracow 1976, pp. 44-45). The list of portraits of Sigismund III Vasa (which, however, does not include the image from Januszowski's diploma) is given by S. Herbst in the paper "Fragmenty ikonografii Zygmunta III Wazy", in Sztuka i historia. Ksiega pamiątkowa ku czci profesora Michała Walickiego, ed. J. Białostocki et al., Warsaw 1966, pp. 114-117. 
(neutral background, the model's posture) and the reconstruction of details. The similarity of facial features with raised eyebrows and prominent nose or expression of swollen eyes looking directly at the viewer is noticeable. The same is true for the beard (pointed moustache, short trimmed beard all over the chin) and the shape of the tightened lips. The details of the outfit are also similar: a tall cap decorated with a bunch of ostrich feathers and surrounded by a band made partly of large shiny pearls. In both portraits, Sigismund III wears a dark cup fastened with golden buttons and a tubular ruff, and his shoulders are covered with a coat lined with fur. In the image of Sigismund III on Januszowski's diploma of nobility-just like in many royal portraits that are repetitions or paraphrases of the painting by Marcin Kober stored in the Wawel Castle collection - there are also some modifications of the model image: the fur under the coat is of a different colour, the cap band is decorated with slightly different jewels, the collar is devoid of a lace finish, and its ends do not rise above the shoulders of the King.

The second of the royal portraits in the painting decoration of Januszowski's diploma is a portrait of the predecessor of Sigismund III Vasa on the Polish throne. The veristic portrait shows Stephen Báthory as a man in his prime. Báthory, who had been dead for years, is depicted with a full face and a curved nose, deep wrinkles on his forehead, a beard, and a characteristic nevus on his right cheek. He is dressed in a red delia, a type of cloak, with a dark fur collar and wears a felt Hungarian-style cap on his head, with a golden cap brooch-like decoration called szkofia. ${ }^{30}$ This portrait was also inspired by Marcin Kober-probably the monumental portrait of Báthory from 1583 signed by the painter. ${ }^{31}$ Although in the two portraits the model-

${ }^{30}$ Elements of Báthory's clothing are characterized by Z. Żygulski, "Akcenty tureckie w stroju Batorego", Folia Historiae Atrium 24 (1988), pp. 61-62.

${ }_{31}$ This majestic portrait, which used to hang in the Wawel Cathedral and is now kept by the Order of the Mission in Stradom, is the inspiration of many of the preserved images of King Báthory. See S. Komornicki, Essai d'une iconographie du roi Etienne Batory, Cracow 1935; E. Błażewska, "Marcin Kober i portrety z jego kręgu", Rocznik Krakowski 47 (1976), pp. 70-73. 
ling of the royal face is not the same, with a different expression and slightly different features, the relationship between the two works is beyond doubt, since not only the composition of the likenesses is the same (although, of course, the image of Kober's authorship is fullfigure), but also the royal costume, the head position, and the look towards the viewer.

The set of royal miniatures on Januszowski's diploma of nobility ends with the portrait of Henry Valois in a purple jacket and a dark coat hanging from his shoulders. The clumsily shaped and conventionally treated face is swollen, with a beard surrounded by a white ruff. He has a string of pearls on his chest, and his head is covered with a soft velvet beret, adorned with jewels and a bunch of feathers. There is no doubt that the illuminator painted this likeness using one of the numerous portraits of the king, also available in the form of prints.

The composition of the three royal likenesses is identical: the entire surface of the oval frame is filled with a head and a small section of arms on a smooth, dark background. When painting his first two busts portraits, the artist based his work on good paintings, which allowed him to clearly individualise the faces of the models. The portraits of Báthory and Vasa were also painted slightly closer-up than the image of Henry III, with a bunch of black feathers on King Stephen's cap and a tall cylindrical hat of young Sigismund going boldly outside the frames of miniatures. Although we do not know the illuminator of Jan Januszowski's diploma, its quality, and especially the masterly execution of the miniatures integrated into the bordure, allows us to guess that he was an artist associated with the patron and the royal court. It is worth noting the high artistic quality of the images and the obvious links between the two of them and the art of Marcin Kober, the court portraitist of Sigismund III Vasa.

The identification of people depicted in portraits included in the illuminated decoration of Januszowski's diploma does not raise any doubts. Firstly, we know their characteristic faces from other portraits from the period and, secondly, the images of the kings feature their symbolic signs: the personal heraldic badges (Vasa's sheaf, Báthory's wolf's fangs, and Angevins' lilies), each time in a cartouche based 
on the upper edge of the portrait frame. However, the oval that was probably to be filled with a miniature portrait of Sigismund Augustus was not crowned with any of the personal badges he used (one could expect here the Pahonia or the Serpent of the Sforzas, the king's family badge). The Grand Ducal arms of Lithuania was painted right next to the portrait frame, on its heraldic right side. The author of the iconographic programme of the illumination certainly knew that the rearing horse-rider was not only a national arms, but also the dynastic badge of the Jagiellons. ${ }^{32}$ The assumption that an image of Sigismund Augustus was planned to be placed in the empty oval in the vicinity of Pahonia is also prompted by the spatial logic of the bordure decoration of Januszowski's diploma. The Polish Eagle was painted on the left margin of the document, with the insignia of royal power and the portrait of the grantor of the document, i.e. the then reigning Sigismund III, below it. On the right margin, there are images (from the bottom edge of the card): Stephen Báthory, the direct predecessor of the young Vasa, and Henry III, the first elected king (it is interesting that next to the frame of his portrait there is a bird rushing to the air, perhaps an allusion to the infamous escape of Henry Valois). The consistency of the composition would therefore require that the portrait of the last Jagiellonian be placed above the portrait of the Polish-French king. It is also worth noting that closing the gallery of royal miniatures with the representation of Sigismund Augustus could be treated as an allusion to the fate of the ennobled Januszowski. He lived first during the reign of the last Jagiellonian (Januszowski was born under his rule, and in his young years worked as a personal scribe for the king), and then Henry III and Báthory (a ruler particularly valued by the printer), and finally Sigismund III Vasa, who was to give Januszowski nobility and the title of arch-typographer.

It should be emphasised that more miniatures were to be painted on this diploma, as two oval frames, in the bottom margin decorations,

${ }^{32}$ Piech, "Zarys dziejów", p. 21. 
were left blank. They were to feature images of Bernard Maciejowski and Jan Zamoyski, as revealed by the personal coats of arms of magnates (Ciołek and Jelita, respectively) and attributes that accompany the empty portrait frames: a cardinal's hat that signifies the ecclesiastical dignity of Maciejowski and a panoply, undoubtedly alluding to the armed successes of Zamoyski. Both magnates were kind to Januszowski. The printer cooperated with Zamoyski for many years, maintaining lively correspondence with him; ${ }^{33}$ he also benefited for a long time from the support that Maciejowski gave to some of his publishing activities (evidenced by allusions scattered by Januszowski in his dedications to books "presented" to the prelate), and in 1603 he was to receive from the cardinal's hand "holy orders and the dignity of the Sandomierz archdeacon and the parish priest in Solec" ${ }^{34}$ It cannot be ruled out that Bernard Maciejowski and Jan Zamoyski were among the senators who influenced Sigismund III Vasa to grant nobility to the distinguished printer since they both took part in the Sejm assembly of 1588 and were close to the young King in the turbulent period that began his reign. The support that Maciejowski and Zamoyski could have given to the cause of Januszowski's ennoblement is difficult to determine unequivocally. Nonetheless, the fact that the painting decor of Januszowski's diploma was to include their images

${ }^{33}$ The letters from Januszowski to Zamoyski were collected by A. KaweckaGryczowa in her book $Z$ dziejów polskiej książki w okresie Renesansu, Warsaw 1975. By the way, it can be added that the hetman's correspondence stored in the Archive of Jan Zamoyski in The Central Archives of Historical Records also shows that Januszowski ordered a portrait of his patron at the beginning of the seventeenth century: "Knut [Samuel, the Zamość court treasurer] was also entrusted by Zamoyski with the care of storing and securing his portrait, made in 1602 in Cracow on Januszowski's order, as well as paintings brought from Italy in 1604 by Montelupi". W. Tygielski, Listy, ludzie, władza. Patronat Jana Zamoyskiego w świetle korespondencji, Warsaw 2007, p. 326.

${ }^{34}$ Starowolski, Setnik, p. 218. Januszowski dedicated his works to Maciejowski: Syjon pochylony (Cracow: Officina Lazari, 1587), Jubileusz wielki (Cracow: Jakub Sibeneicher, 1603), and the work of Father Jan Głuchowski Ikones książat i królów polskich (Cracow: Officina Lazari, 1605). 
is corroborated by the assumption that the person who designed the illumination of the parchment card not only wished to visually present the political system, territories, and authorities of the Commonwealth, but also to emphasise the bonds between Januszowski and the outstanding personalities portrayed on the document confirming his ennoblement.

The miniature portraits, which were included or only planned to be included in the unfinished decoration of Januszowski's diploma, also substantiate a hypothesis regarding the dating of the document. According to the date given in the diploma, Januszowski was awarded nobility on 24 January 1588, but the work on the diploma certifying his ennoblement was certainly carried out in later years since the portrait of Sigismund III was modelled on Marcin Kober's painting from 1591. Perhaps most of the decoration of the document was made in the early 1590s. The research conducted by Jerzy Michta, an expert in ennoblement and indygentat (naturalisation of foreign nobles) in Poland, shows that the composition and quality of the illumination depicting the heraldic decoration of Januszowski's diploma indicate that it was issued by the royal chancery in 1595 , as after that date the style of iconographic representations on diplomas of nobility changed and the artistic quality of images of coats of arms decreased significantly. Perhaps the illuminator, who also worked for Januszowski, died or left Cracow, probably unexpectedly, since the diploma remained unfinished. A hypothesis that the painting decoration of a document was made in the 1590s may be contradicted by the intention to place a portrait frame decorated with a cardinal's hat and intended for the image of Bernard Maciejowski among the floral ornament of the bottom margin, as the prelate did not receive this cardinal's dignity until 1603. I think, however, that the cardinal's hat was painted on the diploma at the beginning of the seventeenth century and included in the iconographic programme of the decoration made earlier, as it was needed at that moment. This is evidenced by the way in which the cords with tassels attached to the hat were depicted, which the artist clearly tried to fit into the narrow space between the frame of the portrait and the winding flowering stem. 
It is possible that this is a trace of the efforts Januszowski could have made to complete the painting decoration of his diploma.

For a historian interested in book culture, the illumination on Januszowski's diploma, so beautiful and with such a rich iconographic programme, is unique for one reason. Among the decorations of the bottom margin, exactly on the axis of the card, there is another portrait medallion. The frame decorated with green acanthus leaves is smaller than those intended for the likenesses of kings and magnates. It was filled with an image that is especially valuable for scholars because it probably represents Jan Januszowski himself. From the miniature, a serious grey man looks directly at the viewer. The view is almost exactly frontal, with an uncovered head (while all the kings were painted in the "three-quarter" view and with caps), set on a short neck covered with an elegant Spanish beard. The man wears a black outfit, discreetly illuminated by the white of a narrow collar. The model has an expressive, oval face, regular but heavy features: a calm, wide forehead, big, dark eyes highlighted with strong modelling under slightly frowned eyebrows, a massive nose, lips with a strong expression. The image is certainly not conventional or typified, and its individualisation reveals not only the hand of a very good painter, but also suggests that he observed his model and rendered his real features.

The portrait is modest, devoid of attributes that could suggest Januszowski's writing or printing activities. This was perhaps in accordance with the Renaissance custom, which meant that contemporary intellectuals, scholars, and poets were often shown without reference to their profession and work, as viri illustres, whose achievements justified preserving their appearance without the need to substantiate it in their portraits. ${ }^{35}$

Should we assume that the miniature is a credible image of the ennobled Januszowski? In my opinion, any other hypothesis is unlikely. Whose likeness should be more rightly recorded in the document

35 J. Białostocki, "Renesansowy portret pisarza", in Portret. Funkcja - forma symbol, ed. A. Marczak-Krupa, Warsaw 1990, p. 110. 
confirming the granting of nobility than that of the interested party himself? Whose portrait could become an element of the painting decoration of the diploma that Januszowski ordered and paid for if not his own?

Such an idea seems to be corroborated by the spatial affinity of the illumination of the diploma. Well, although the enigmatic miniature, like the images of rulers, was presented in a cartouche with a folded ornament typical of the Renaissance, the frame was not topped with any heraldic symbols. Apparently, it was not necessary: the coat of arms-Kłośnik-was painted just above the portrait, and the two representations were separated with only a few lines of the text of the diploma. The small portrait and the coat of arms depicted with full splendour-both distinguished by their position on the axis of the parchment card-remain in a relationship, which is not evident at first glance.

The first biographer of Januszowski, Szymon Starowolski, has already stated that Januszowski's diploma was made with a "proficient hand". We are not able to find a face or name for this hand since the sources of the second half of the sixteenth century mention more than seventy painters who worked in Cracow at that time. ${ }^{36}$ It is also possible that the beauty of Jan Januszowski's diploma of nobility should be attributed to several people, since it is known that in mediaeval and Renaissance Cracow, which was a large artistic centre, the producers of illuminated manuscripts, both books and decorated documents, eagerly specialised, separating and improving the competences of scribes and painters. The iconographic concept was often defined by the client, usually auctor intellectualis, a scholar who understood the text and was aware of the ideological functions that the manuscript

${ }^{36}$ T. Dobrowolski, Polskie malarstwo portretowe. Ze studiów nad sztukq̨ epoki sarmatyzmu, Cracow 1948, pp. 86-87. 
was supposed to fulfil- “the illuminators' task was to translate his instructions into the language of images" ${ }^{37}$

The extensive, multi-layered iconographic programme of Jan Januszowski's diploma of nobility was certainly the result of reflections and work of an educated man familiar with the visual tradition of his time, who understood both the textual and pictorial language. This man, probably using the resources of his own memory, the wisdom of books, and conversations with scribes and illuminators who knew their trade, was able to make the decoration of the official document complement its text. The illumination of the privilege emphasised the solemnity and uniqueness of the ennoblement, which the diploma attested to, underlined the supernatural character and ancient roots of the power of the monarch who conferred the nobility and defined the territorial structure of the vast and powerful Polish-Lithuanian Commonwealth. Using visual means, it symbolically referred to the witnesses to the legal act performed by kings and magnates, who knew the ennobled and could confirm his merits. And finally, it passed on to posterity-not by word but by brush - the portrait of a burgher who was made a nobleman.

Of course, it is not excluded that the author of the iconographic concept of the artistic decoration of this diploma was Januszowski himself-a man not only educated, but also accustomed to close cooperation with artists and illustrators due to the decades of his profession. Januszowski certainly wanted to influence the look and spirit of the document he ordered and paid for dearly. Perhaps he also wished that the diploma, which was clear evidence of the broad recognition of his personal qualities and accomplishments in the service of "God and his Church, as well as his homeland", ${ }^{38}$ would include his portrait

37 B. Miodońska, "Organizacja i technika pracy iluminatorów małopolskich w latach 1400-1520", in Symbolae Historiae Artium. Studia z historii sztuki Lechowi Kalinowskiemu dedykowane, ed. J. Gadomski et al., Warsaw 1986, pp. 330-333.

38 J. Januszowski, Nowy karakter polski, Cracow: Officina Lazari, 1594, f. A 2 r. 
and perpetuate his features, which would be another Renaissance proof of existence beside his printing and writing output.

Unfortunately, there is no other known likeness of Januszowski or any description of his looks. A comparison is therefore impossible. It remains a very probable hypothesis that Januszowski's features were recorded, probably ad vivum, by an anonymous illuminator of the printer's diploma of nobility and that he is indeed looking towards us from the miniature portrait.

Translated from Polish by Kaja Szymańska

\section{Bibliography}

\section{Primary sources}

Głuchowski, J., Ikones książąt i królów polskich, Cracow: Officina Lazari, 1605. Januszowski, J., Jubileusz wielki, Cracow: Jakub Sibeneicher, 1603. Januszowski, J., Nowy karakter polski, Cracow: Officina Lazari, 1594. Januszowski, J., Syjon pochylony, Cracow: Officina Lazari, 1587.

\section{Secondary sources}

Białostocki, J., "Renesansowy portret pisarza", in Portret. Funkcja-forma-symbol, ed. A. Marczak-Krupa, Warsaw 1990.

Birkenmajer, A., Nobilitacja Szarffenbergerów, Cracow 1926.

Błażewska, E., "Marcin Kober i portrety z jego kręgu", Rocznik Krakowski 47 (1976).

Bodniak, S., "W oficynie „architypografa”. Rzecz o kłopotach Januszowskiego", Silva Rerum 5 (1930).

Chorążyczewski, W., "Nowożytny dokument królewski. Możliwości badawcze", in Polska kancelaria królewska czasów nowożytnych. Między władzą a społeczeństwem, ed. W. Chorążyczewski and W. Krawczuk, Toruń 2003.

Chrościcki, J. A., Sztuka i polityka. Funkcje propagandowe sztuki w epoce Wazów, 1587-1668, Warsaw 1983.

Czyż, P. P., "Dominik Witke-Jeżewski", in Miłośnicy grafiki i ich kolekcje w zbiorach Muzeum Narodowego w Warszawie, ed. E. Zdonkiewicz, Warsaw 2006, pp. 116-119.

Dobrowolski, T., Polskie malarstwo portretowe. Ze studiów nad sztuką epoki sarmatyzmu, Cracow 1948. 
Gieysztor, A., "Non habemus caesarem nisi regem. Korona zamknięta królów polskich w końcu XV wieku i w wieku XVI", in Muzeum i twórca. Studia z historii sztuki i kultury ku czci prof. Stanisława Lorentza, ed. K. Michałowski et al., Warsaw 1969, pp. 277-292.

Herbst, S., "Fragmenty ikonografii Zygmunta III Wazy", in Sztuka i historia. Księga pamiatkowa ku czci profesora Michała Walickiego, ed. J. Białostocki et al., Warsaw 1966, pp. 114-117.

Jaworska, A., Orzeł biały. Herb państwa polskiego, Warsaw 2003.

Jaworska, A., "Znaki władcy i państwa w heraldyce nobilitacji i indygenatu w Polsce", in Ludzie i herby w dawnej Polsce, ed. P. Dymmel, Lublin 1995.

Kawecka-Gryczowa, A., "Bazylik Cyprian”, in: Drukarze dawnej Polski od XV do XVIII wieku, vol. 5: Wielkie Księstwo Litewskie, ed. A. Kawecka-Gryczowa, K. Korotajowa, and W. Krajewski, Wrocław 1959.

Kawecka-Gryczowa, A., "Dzieje 'Drukarni Latającej”", Rocznik Biblioteki Narodowej 7 (1971).

Kawecka-Gryczowa, A., "Jan Januszowski", in Drukarze dawnej Polski, vol. 1: Małopolska, part 1: OdXV do XVI wieku, ed. A. Kawecka-Gryczowa, Wrocław 1983, pp. 69-99.

Kawecka-Gryczowa, A., Z dziejów polskiej książki w okresie Renesansu, Warsaw 1975.

Kiliańczyk-Zięba, J., Czcionką i piórem. Jan Januszowski w roli pisarza i tłumacza, Cracow 2007.

Komornicki, S., Essai d'une iconographie du roi Etienne Batory, Cracow 1935.

Korolko, M., Seminarium Rzeczypospolitej Królestwa Polskiego. Humaniśsi w kancelarii królewskiej Zygmunta Augusta, Warsaw 1991.

Kuczyński, S. K., "Nobilitacja Szymona Szymonowica”, Rocznik Lubelski 25/26 (1983/1984), pp. 31-43.

Kuczyński, S. K., Polskie herby ziemskie. Geneza, treści, funkcje, Warsaw 1993.

Lileyko, J., Regalia polskie, Warsaw 1987.

Michta, J., Nobilitacja Jana Januszowskiego wystawiona w Krakowie, 24 stycznia 1588 roku, Kielce 1991 (Nobilitacje i Indygenaty w Rzeczypospolitej 1434-1794, no. 3).

Miodońska, B., "Korona zamknięta w przekazach ikonograficznych z czasów Zygmunta I", Biuletyn Historii Sztuki 32 (1970), no. 1, pp. 3-15.

Miodońska, B., "Organizacja i technika pracy iluminatorów małopolskich w latach 1400-1520", in Symbolae Historiae Artium. Studia z historii sztuki Lechowi Kalinowskiemu dedykowane, ed. J. Gadomski et al., Warsaw 1986.

Miodońska, B., "Przedstawienie państwa polskiego w Statucie Łaskiego z r. 1506", Folia Historiae Atrium 5 (1968), pp. 38-47.

Muzeum Narodowe w Warszawie. Przewodnik po galeriach stałych i zbiorach studyjnych, ed. K. Murawska-Muthesius and D. Folga-Januszewska, Warsaw 1998.

Paprocki, B., Herby rycerstwa polskiego, ed. K. J. Turowski, Cracow 1858.

Petrus, T., "Miniaturowa galeria portretów rodziny Zygmunta III", Biuletyn Historii Sztuki 37 (1975), pp. 150-161. 
Piech, Z., "Zarys dziejów i symbolika orła białego", in Orły nasze. Orzeł biały w zbiorach Biblioteki Jagiellońskiej, ed. M. Rokosz, Cracow 1996.

Piekarski, K., Pierwsza drukarnia Floriana Unglera, 1510-1516, Cracow 1926.

Ptaśnik, J., Cracovia impressorum XV et XVI saeculorum, Lviv 1922 (Monumenta Poloniae Typographica I).

Ruszczycówna J., "Portrety Zygmunta III i jego rodziny", Rocznik Muzeum Narodowego w Warszawie 13 (1969), no. 1.

Słowiński, J., Rozwój pisma łacińskiego w Polsce w XVI-XVIII wieku. Studium paleograficzne, Lublin 1992.

Starowolski, S., Setnik pisarzów polskich, ed. F. Bielak and J. Starnawski, transl. J. Starnawski, Cracow 1970.

Sułkowska-Kurasiowa, I., Dokumenty królewskie i ich funkcja w państwie polskim za Andegawenów i pierwszych Jagiellonów, 1370-1444, Warsaw 1977.

Sułkowska-Kurasiowa, I., "Księgi wpisów Metryki Koronnej (1447-1794) w Archiwum Głównym Akt Dawnych w Warszawie", Archeion 44 (1966).

Sztuka dworu Wazów w Polsce. Wystawa w Zamku Królewskim na Wawelu, majczerwiec 1976. Katalog, ed. A. Fischinger, Cracow 1976.

Szymański, J., Nauki pomocnicze historii, Warsaw 2006.

Tomczak, A., "Kilka uwag o kancelarii królewskiej w drugiej połowie XVI wieku", Archeion 37 (1962).

Tomkowicz, S., Przyczynki do historii kultury Krakowa w pierwszej połowie XVII wieku, Lviv 1912.

Trelińska, B., Album armorum nobilium Regni Poloniae XV-XVIII saec. Herby nobilitacji i indygenatów XV-XVIII w., Lublin 2001.

Tygielski, W., Listy, ludzie, władza. Patronat Jana Zamoyskiego w świetle korespondencji, Warsaw 2007.

Wierzbowski, T., Materialy do dziejów piśmiennictwa polskiego, Warsaw 1900.

Znamierowski, A., Insygnia, symbole i herby polskie, Warsaw 2003.

Żygulski, Z., "Akcenty tureckie w stroju Batorego", Folia Historiae Atrium 24 (1988). 